AGRIEKONOMIKA

http://journal.trunojoyo.ac.id/agriekonomika

Volume 9, Nomor 2, 2020

https://doi.org/10.21107/agriekonomika.v9i2.8033
Agriekonomika has been accredited as a scientific journal by the Ministry of Research-Technology and Higher Education Republic of Indonesia: No. 23/E/KPT/2019

\title{
Pemanfaatan Etnobotani Masyarakat Tengger Untuk Obat Herbal dan Upacara Adat
}

SINTA 2

Anggita Anugra Sari \& ${ }^{凶}$ Yuli Hariyati

Program Studi Agribisnis Universitas Jember, Indonesia

Received: July 2020; Accepted: October 2020; Published: October 2020

\begin{abstract}
ABSTRAK
Penurunan ketersediaan tanaman etnobotani baik untuk obat herbal maupun upacara adat di Desa Ngadisari diakibatkan oleh rendahnya minat masyarakat untuk melakukan budidaya. Tujuan penelitian ini adalah untuk mengetahui persepsi masyarakat Tengger dalam pemanfaatan tanaman etnobotani di Desa Ngadisari. Metode yang digunakan adalah skala likert. Hasil analisis menunjukkan bahwa persepsi masyarakat dalam pemanfaatannya sebagai obat herbal antara lain berdasarkan tingkat kebutuhan sebesar 4,4, penggunaan 3,3, keberhasilan 2,8 dan kemudahan bahan didapat 3,4. Besar persepsi masyarakat dalam pemanfaatannya sebagai upacara adat berdasarkan tingkat kebutuhannya sebesar 13,3, penggunaan 7,5, keberhasilan 9,0 dan kemudahan bahan didapat 8,9. Disimpulkan bahwa persepsi masyarakat dalam pemanfaatan tanaman etnobotani untuk obat herbal tergolong sangat rendah dengan nilai sebesar 13,9 , sedangkan pemanfaatan tanaman etnobotani untuk upacara adat tergolong sangat tinggi dengan nilai sebesar 38,7.
\end{abstract}

Kata Kunci: Persepsi, Masyarakat Tengger, Tanaman Etnobotani

Perception Utilization Ethnobotany in Ngadisari Village Sukapura Sub-District Probolinggo Regency

\begin{abstract}
The decline in the availability of ethnobotany plants for both herbal medicine and traditional ceremonies in Ngadisari Village is due to the low interest of the community in cultivating. The purpose of this study was to determine the perception of the Tengger community in the use of ethnobotany plants in Ngadisari Village. The method used is the Likert scale. The results of the analysis show that the public perception of its use as herbal medicine is based on the level of need of 4.4, the use of 3.3, the success of 2.8 and the ease with which the ingredients are obtained, 3.4. The perception of the community in its use as a traditional ceremony based on the level of need was 13.3, 7.5 use, success 9.0 and the ease of obtaining the material was 8.9. It was concluded that the public perception of the use of ethnobotany plants for herbal medicine was classified as very low with a value of 13.9, while the use of ethnobotany plants for traditional ceremonies was classified as very high with a value of 38.7 .
\end{abstract}

Keywords: Perception, Tengger Society, Ethnobotany Plants

\section{PENDAHULUAN}

Ketersediaan tanaman di Indonesia sangat melimpah dimana dapat dimanfaatkan oleh masyarakat untuk memenuhi kebutuhan sehari-hari, salah satunya yaitu tanaman etnobotani. Menurut Batoro (2015), etnobotani merupakan ilmu yang menjelaskan pemanfaatan dan 
pengelolaan tanaman tradisional oleh masyarakat terhadap lingkungan sekitar. Etnobotani juga mempelajari hubungan manusia dengan lingkungannya, dimana lingkungan alam telah menyediakan sumber daya alam yang sangat melimpah.

Menurut Walujo (2011), etnobotani menjelaskan bahwa masyarakat memiliki ketergantungan dengan tanaman di lingkungan sekitar, baik secara langsung ataupun tidak langsung. Masyarakat di Indonesia yang memanfaatkan tanaman etnobotani salah satunya yaitu masyarakat Tengger. Masyarakat Tengger sangat taat kepada adat dan budaya yang diwariskan oleh leluhur, dimana mereka tidak mengenal kasta sehingga persaudaraan antara yang satu dengan yang lain sangat erat (Batoro, 2017). Masyarakat Tengger mendiami beberapa kabupaten di Provinsi Jawa Timur antara lain Kabupaten Pasuruan, Lumajang, Malang dan Probolinggo (Ningsih, 2016).

Menurut Batoro dkk. (2011), masyarakat Tengger dalam memanfaatkan tanaman etnobotani beranekaragam penggunaannya antara lain digunakan untuk obat herbal dan ritual upacara adat. Tanaman etnobotani mayoritas tumbuhnya di hutan, dimana mereka sangat menggantungkan kehidupannya pada berbagai sumber daya yang ada di hutan untuk memenuhi kebutuhan sehari-hari. Mereka beranggapan bahwa semua sumber daya yang ada di hutan merupakan anugerah Sang Hyang Widhi untuk dimanfaatkan dalam memenuhi kebutuhan hidupnya terutama sebagai obat herbal dan upacara adat.

Menurut Kurniawan \& Jadid (2015), pemanfaatan tanaman etnobotani sebagai obat herbal sudah berlangsung sejak lama. Masyarakat Tengger pun telah mengetahui tanaman apa saja yang berpotensi untuk obat herbal karena pengetahuan tersebut sudah diwariskan oleh leluhur-leluhurnya. Masyarakat tradisional menganggap bahwa obat herbal jauh lebih aman untuk dikonsumsi. Menurut Atmojo (2015), pemanfaatan tanaman obat dapat menjadi pilihan utama masyarakat karena akses fasilitas kesehatan yang jauh serta harga obat yang mahal. Masyarakat memanfaatkan tanaman obat tersebut karena setiap tanaman memiliki khasiat masing-maisng dalam menyembuhkan penyakit. Pengenalan tanaman sebagai obat dapat memberikan perubahan tentang pengetahuan awal masyarakat mengenai jenis tanaman yang dapat dimanfaatkan sebagai obat. Tanaman etnobotani telah lama digunakan oleh masyarakat dalam mengobati penyakit, dimana para ahli menyimpulkan bahwa sejak zaman prasejarah manusia yang hidup sekitar 60.000 tahun lalu sudah memanfaatkan tanaman obat. Dunia kedokteran mencatat sekitar 20.000 jenis tanaman obat yang dikenal di dunia. Di luar jumlah tersebut, diperkirakan terdapat sekitar 70.000 spesies tumbuhan yang bisa digunakan sebagai bahan obat (Savitri, 2016).

Masyarakat Tengger memanfaatkan tanaman etnobotanijuga untuk kepentingan ritual dalam upacara adat. Menurut Pramita dkk. (2013), upacara adat atau upacara tradisional merupakan kegiatan sosial yang dilakukan oleh masyarakat di suatu daerah untuk mencapai tujuan keselamatan bersama. Mereka secara bersama-sama melakukan upacara tersebut mengikuti tradisi yang telah dilakukan oleh leluhurleluhurnya untuk memperoleh keselamatan bersama dan dapat menjadikan rasa kebersamaan antar masyarakat semakin kuat. Menurut Hasanah dkk. (2014), pemanfaatan tanaman dalam upacara adat sebagian besar masih dilakukan oleh masyarakat yang bertempat tinggal di daerah pedesaan. Penggunaan tanaman sebagai sesajen dalam upacara adat tersebut didasarkan atas kepercayaan dan tradisi yang tidak dapat dipisahkan dari tanaman. Mereka menganggap bahwa tanaman tersebut dianggap sebagai salah satu bagian penting dalam pelaksanaan ritual upacara adat. Menurut Badan Pusat Statistik (2019), jumlah masyarakat yang hindu di Desa Ngadisari menempati posisi pertama dari 12 desa yang terdapat di Kecamatan Sukapura yang akan disajikan pada tabel berikut ini. 
Tabel 1

Jumlah Masyarakat Hindu di Kecamatan Sukapura pada Tahun 2019

\begin{tabular}{llll}
\hline No. & Desa & Jumlah & Persentase (\%) \\
\hline 1 & Ngadisari & 1447 & 21,48 \\
2 & Sariwani & 607 & 9,01 \\
3 & Kedasih & 265 & 3,93 \\
4 & Pakel & 217 & 3,22 \\
5 & Ngepung & 3 & 0,04 \\
6 & Sukapura & 5 & 0,07 \\
7 & Sapikerep & 1030 & 15,29 \\
8 & Wonokerto & 3 & 0,04 \\
9 & Ngadirejo & 1343 & 19,94 \\
10 & Ngadas & 653 & 9,69 \\
11 & Jetak & 536 & 7,96 \\
12 & Wonotoro & 627 & 9,31 \\
\hline
\end{tabular}

Sumber: Kecamatan Sukapura dalam Angka 2019 (BPS)

Berdasarkan tabel 1, dapat diketahui bahwa jumlah masyarakat hindu yang ada di Desa Ngadisari menempati posisi pertama dengan jumlah 1447 orang atau $21,48 \%$. Hal tersebut membuktikan bahwa kebutuhan tanaman etnobotani oleh masyarakat baik sebagai obat herbal maupun tanaman upacara adat semakin banyak. Menurut Astriyantika dkk., (2014), kebutuhan masyarakat tersebut mengartikan bahwa sumberdaya alam memiliki nilai ekonomi yang tinggi meskipun tidak dapat dirasakan secara fisik atau dalam bentuk uang karna tanaman tersebut menjadi pemenuh kebutuhan sehari-hari terutama dalam upacara adat. Meningkatnya jumlah kebutuhan masyarakat terhadap tanaman etnobotani nyatanya berbanding terbalik dimana jumlah tanaman etnobotani yang ada di Desa Ngadisari semakin berkurang. Penyebabnya yaitu rendahnya minat masyarakat untuk melakukan budidaya tanaman etnobotani. Berdasarkan latar belakang tersebut, maka penelitian ini bertujuan untuk mengetahui bagaimana persepsi masyarakat suku Tengger dalam memanfaatkan tanaman etnobotani di Desa Ngadisari Kecamatan Sukapura Kabupaten Probolinggo.

\section{METODE PENELITIAN}

Penelitian ini dilakukan di Desa Ngadisari Kecamatan Sukapura Kabupaten Probolinggo karena menjadi desa penganut agama hindu terbanyak daripada desa yang lainnya. Metode penelitian yang digunakan yaitu metode analitis. Jenis data yang digunakan yaitu data sekunder dan data primer. Data sekunder berupa data masyarakat yang beragama hindu di Desa Ngadisari yang diperoleh dari Badan Pusat Statistik. Data primer diperoleh dari kegiatan wawancara dengan ibu rumah tangga yang ada di Desa Ngadisari. Penentuan responden dilakukan menggunakan metode snowball sampling. Berdasarkan hasil snowball sampling diketahui bahwa jumlah responden dalam penelitian ini sebanyak 30 yang terdiri atas 5 orang di Dusun Wanasari, 20 orang di Dusun Ngadisari dan 5 orang di Dusun Cemara Lawang.

Analisis data yang digunakan dalam penelitian ini yaitu skala likert. Menurut Sianipar dan Entang dalam Indarwati dkk., (2015), Penilaian dengan metode skala likert dilakukan menggunakan rating scale yang kemudian akan dikonversikan dalam bentuk angka. Penilaian terhadap beberapa kriteria tersebut selanjutnya 
dilakukan dengan memberi skor antara 1 sampai dengan 5 pada setiap jawaban yang dipilih oleh responden pada setiap itemnya. Berikut akan disajikan skor beserta penjelasan dari masing-masing skor tersebut untuk mengetahui nilai persepsi masyarakat dalam pemanfaatan tanaman etnobotani sebagai obat herbal maupun untuk keperluan upacara adat (Riduwan, 2018)

a. Skor 5 untuk jawaban sangat tinggi

b. Skor 4 untuk jawaban tinggi

c. Skor 3 untuk jawaban cukup tinggi

d. Skor 2 untuk jawaban rendah

e. Skor 1 untuk jawaban rendah sekali

Setelah penentuan skor untuk setiap item pertanyaan, maka selanjutnya dilakukan perhitungan skor menggunakan skala Likert dimana rumusnya akan disajikan sebagai berikut (Juwita dkk., 2014).

$R S=m-n / b$

Dimana RS merupakan rentang skala, $\mathbf{m}$ adalah angka tertinggi dalam pengukuran (jumlah pertanyaan $\mathrm{x}$ skor tertinggi), $\mathbf{n}$ adalah angka terendah dalam pengukuran (jumlah pertanyaan $\mathrm{x}$ skor terendah) dan $\mathbf{b}$ adalah banyak kelas.

Dalam menentukan skor tiap kriterianya dapat dihitung dengan menggunakan rumus berikut.

Rata-rata skor $=\frac{\text { Total skor }}{\text { Jumlah responden }}$

Menurut Ukkas (2017), skala likert digunakan untuk mengukur seberapa besar sikap, pendapat maupun persepsi dari seseorang terhadap suatu objek yang diamati. Persepsi merupakan suatu proses penilaian dalam penangkapan arti objek-objek sosial dan kejadian-kejadian yang kita alami (Mulyana dalam Panuju, 2018). Persepsi masyarakat terhadap pemanfaatan tanaman etnobotani diukur berdasarkan 4 kriteria yaitu tingkat kebutuhan, penggunaan, keberhasilan, dan kemudahan bahan didapat. Berikut akan disajikan tabel mengenai kriteria yang mendasari penilaian persepsi ibu rumah tangga dalam memanfaatkan tanaman etnobotani menurut (Sidik \& Fatmawati, 2019)

\section{HASIL DAN PEMBAHASAN}

Tanaman etnobotani oleh masyarakat Tengger di Desa Ngadisari Kecamatan Sukapura Kabupaten Probolinggo dimanfaatkan sebagai obat herbal dan sesajen pada upacara adat. Masyarakat memanfaatkan tanaman etnobotani tersebut sudah berlangsung sejak lama dan hingga saat ini pun masih ada yang menggunakannya, dimana penggunaan tanaman etnobotani tersebut menjadi suatu tradisi yang diturunkan secara turun-temurun. Pemanfaatan tanaman etnobotani tentu dapat dilihat dari seberapa besar persepsi masyarakat terhadap penggunaan tanaman etnobotani. Persepsi masyarakat dapat dilihat dari beberapa kriteria penilaian yaitu tingkat kebutuhan, penggunaan, keberhasilan dan kemudahan bahan didapat. Berikut akan disajikan penjelasan mengenai kriteria untuk mengetahui bagaimana persepsi masyarakat dalam pemanfaatan tanaman etnobotani di Desa Ngadisari Kecamatan Sukapura Kabupaten Probolinggo.

\section{Tingkat Kebutuhan}

Tingkat kebutuhan setiap masyarakat tentu berbeda-beda karena tergantung kepentingan masing-masing. Besar tingkat kebutuhan masyarakat dalam memanfaatkan tanaman etnobotani dilihat dari beberapa kriteria yaitu kesesuaian kebutuhan masyarakat, kebutuhan sebagai penyembuhan penyakit dan penggunaan upacara adat serta penggunaan secara turun-temurun. Berikut akan disajikan penilaian masyarakat mengenai tingkat kebutuhan terhadap persepsi pemanfaatan tanaman etnobotani.

Berdasarkan tabel 3, dapat diketahui penilaian masyarakat dalam pemanfaatan tanaman etnobotani sebagai obat herbal pada indikator tingkat kebutuhan. Terdapat 3 kriteria penilaian yang digunakan antara lain kesesuaian kebutuhan masyarakat, kebutuhan sebagai penyembuhan penyakit dan penggunaan secara turun-temurun. 
Tabel 2

Kriteria Persepsi Masyarakat dalam Pemanfaatan Tanaman Etnobotani

\begin{tabular}{|c|c|c|}
\hline Kriteria & Obat Herbal & Upacara Adat \\
\hline \multirow[t]{3}{*}{ Tingkat Kebutuhan } & $\begin{array}{l}\text { Kesesuaian kebutuhan masyarakat } \\
(1-5)\end{array}$ & $\begin{array}{l}\text { Kesesuaian kebutuhan } \\
\text { masyarakat }(1-5)\end{array}$ \\
\hline & $\begin{array}{l}\text { Kebutuhan sebagai penyembuhan } \\
\text { penyakit (1-5) }\end{array}$ & $\begin{array}{l}\text { Kebutuhan sebagai keperluan } \\
\text { upacara adat (1-5) }\end{array}$ \\
\hline & $\begin{array}{l}\text { Penggunaan secara turun-temurun } \\
(1-5)\end{array}$ & $\begin{array}{l}\text { Penggunaan secara turun- } \\
\text { temurun }(1-5)\end{array}$ \\
\hline \multirow[t]{2}{*}{ Tingkat Penggunaan } & Frekuensi pemakaian (1-5) & Frekuensi pemakaian (1-5) \\
\hline & $\begin{array}{l}\text { Pengguna semua golongan usia } \\
(1-5)\end{array}$ & $\begin{array}{l}\text { Pengguna semua golongan } \\
\text { usia (1-5) }\end{array}$ \\
\hline \multirow[t]{2}{*}{ Tingkat Keberhasilan } & $\begin{array}{l}\text { Penggunaan tanaman obat oleh } \\
\text { masyarakat }(1-5)\end{array}$ & $\begin{array}{l}\text { Penggunaan tanaman } \\
\text { keperluan upacara adat oleh } \\
\text { masyarakat }(1-5)\end{array}$ \\
\hline & Konsistensi penggunaan (1-5) & Konsistensi penggunaan (1-5) \\
\hline \multirow[t]{2}{*}{$\begin{array}{l}\text { Tingkat Kemudahan } \\
\text { Bahan Didapat }\end{array}$} & $\begin{array}{l}\text { Kemudahan tanaman obat untuk } \\
\text { didapatkan (1-5) }\end{array}$ & $\begin{array}{l}\text { Kemudahan tanaman upacara } \\
\text { adat untuk didapatkan (1-5) }\end{array}$ \\
\hline & $\begin{array}{l}\text { Ketersediaan tanaman obat di tegal/ } \\
\text { hutan }(1-5)\end{array}$ & $\begin{array}{l}\text { Ketersediaan tanaman upacara } \\
\text { adat di tegal/hutan (1-5) }\end{array}$ \\
\hline
\end{tabular}

Sumber: Sidik dan Fatmawati, 2019

Berdasarkan tingkat kebutuhannya dapat diketahuibahwahasildaripenilaian persepsi dengan menggunakan 3 kriteria penilaian dihasilkan rata-rata skornya sebesar 4,4 . Nilai tersebut berada pada rentang skala 3 - 5,3, dimana mengartikan bahwa persepsi masyarakat dalam pemanfaatan tanaman etnobotani sebagai obat herbal tergolong rendah sekali. Berdasarkan hasil lapang, masyarakat saat ini mulai banyak yang beralih menggunakan obat kimia daripada menggunakan tanaman obatherbal, karena mereka beranggapan bahwa proses dalam penyembuhan menggunakan obat kimia lebih cepat jika dibandingkan dengan menggunakan tanaman obat herbal. Oleh karena itu kebutuhan masyarakat Tengger yang berada di Desa Ngadisari terhadap tanaman obat herbal untuk menyembuhkan penyakit semakin berkurang.

Penilaian persepsi masyarakat Tengger di Desa Ngadisari Kecamatan Sukapura Kabupaten Probolinggo berdasarkan tingkat kebutuhan dalam pemanfaatannya dalam upacara adat juga menggunakan 3 kriteria penilaian. Adapun kriteria penilaian yang digunakan antara lain kesesuaian kebutuhan masyarakat, kebutuhan sebagai keperluan upacara adat dan penggunaan secara turuntemurun. Berikut akan disajikan tabel mengenai penilaian masyarakat dalam pemanfaatan tanaman etnobotani untuk keperluan upacara adat.

Berdasarkan tabel 4 , terdapat 3 kriteria penilaian yang digunakan untuk mengetahui nilai persepsi masyarakat berdasarkan tingkat kebutuhannya antara lain kesesuaian kebutuhan masyarakat, kebutuhan sebagai keperluan upacara adat dan penggunaan secara turuntemurun. Berdasarkan penilaian tersebut dapat diketahui bahwa besar nilai persepsi masyarakat dalam pemanfaatan tanaman etnobotani untuk keperluan upacara adat berdasarkan tingkat kebutuhannya menghasilkan total nilai sebesar 13,3. Perolehan hasil total nilai sebesar 13,3 berada pada rentang skala 12,6 - 15, dimana nilai tersebut mengartikan bahwa persepsi masyarakat Tengger untuk keperluan upacara adat berdasarkan tingkat kebutuhannya tergolong dalam kategori sangat tinggi. Masyarakat tengger sangat membutuhkan tanaman etnobotani tersebut sebagai sesajen dalam mengikuti 
Tabel 3

Penilaian Tingkat Kebutuhan Terhadap Persepsi Masyarakat dalam Pemanfaatan Tanaman Etnobotani sebagai Obat Herbal

\begin{tabular}{|c|c|c|c|c|c|c|c|c|}
\hline Kriteria Penilaian & & $\begin{array}{c}1 \\
\text { (RS) }\end{array}$ & $\begin{array}{c}2 \\
(\mathrm{R}) \\
\end{array}$ & $\begin{array}{c}3 \\
(\mathrm{CT}) \\
\end{array}$ & $\begin{array}{c}4 \\
(\mathrm{~T}) \\
\end{array}$ & $\begin{array}{c}5 \\
(\mathrm{ST}) \\
\end{array}$ & $\begin{array}{l}\text { Total } \\
\text { Skor }\end{array}$ & $\begin{array}{l}\text { Rata- } \\
\text { rata Skor }\end{array}$ \\
\hline \multirow{2}{*}{$\begin{array}{l}\text { Kesesuaian } \\
\text { kebutuhan } \\
\text { masyarakat }\end{array}$} & $\begin{array}{l}\text { Jumlah } \\
\text { Orang }\end{array}$ & 8 & 22 & 0 & 0 & 0 & - & - \\
\hline & $\begin{array}{l}\text { Nilai } \\
\text { Skor }\end{array}$ & 8 & 44 & 0 & 0 & 0 & 52 & 1,7 \\
\hline \multirow{2}{*}{$\begin{array}{l}\text { Kebutuhan } \\
\text { sebagai } \\
\text { penyembuhan } \\
\text { penyakit }\end{array}$} & $\begin{array}{l}\text { Jumlah } \\
\text { Orang }\end{array}$ & 18 & 12 & 0 & 0 & 0 & - & - \\
\hline & $\begin{array}{l}\text { Nilai } \\
\text { Skor }\end{array}$ & 18 & 24 & 0 & 0 & 0 & 42 & 1,4 \\
\hline \multirow{3}{*}{$\begin{array}{l}\text { Penggunaan } \\
\text { secara turun- } \\
\text { temurun }\end{array}$} & $\begin{array}{l}\text { Jumlah } \\
\text { Orang }\end{array}$ & 21 & 9 & 0 & 0 & 0 & - & - \\
\hline & $\begin{array}{l}\text { Nilai } \\
\text { Skor }\end{array}$ & 21 & 18 & 0 & 0 & 0 & 39 & 1,3 \\
\hline & & & & & & & Total & 4,4 \\
\hline
\end{tabular}

Sumber: Data Primer Diolah, 2020

Tabel 4

Penilaian Tingkat Kebutuhan Terhadap Persepsi Masyarakat dalam Pemanfaatan Tanaman Etnobotani dalam Upacara Adat

\begin{tabular}{|c|c|c|c|c|c|c|c|c|}
\hline Kriteria Penilaian & & $\begin{array}{c}1 \\
(\mathrm{RS}) \\
\end{array}$ & $\begin{array}{c}2 \\
(\mathrm{R}) \\
\end{array}$ & $\begin{array}{c}3 \\
(\mathrm{CT}) \\
\end{array}$ & $\begin{array}{c}4 \\
(T) \\
\end{array}$ & $\begin{array}{c}5 \\
\text { (ST) } \\
\end{array}$ & $\begin{array}{l}\text { Total } \\
\text { Skor }\end{array}$ & $\begin{array}{c}\text { Rata-rata } \\
\text { Skor }\end{array}$ \\
\hline \multirow{2}{*}{$\begin{array}{l}\text { Kesesuaian } \\
\text { kebutuhan } \\
\text { masyarakat }\end{array}$} & $\begin{array}{l}\text { Jumlah } \\
\text { Orang }\end{array}$ & 0 & 0 & 0 & 15 & 15 & - & - \\
\hline & $\begin{array}{l}\text { Nilai } \\
\text { Skor }\end{array}$ & 0 & 0 & 0 & 60 & 75 & 135 & 4,5 \\
\hline \multirow{2}{*}{$\begin{array}{l}\text { Kebutuhan } \\
\text { sebagai } \\
\text { keperluan } \\
\text { upacara } \\
\text { adat }\end{array}$} & $\begin{array}{l}\text { Jumlah } \\
\text { Orang }\end{array}$ & 0 & 0 & 0 & 13 & 17 & - & - \\
\hline & $\begin{array}{l}\text { Nilai } \\
\text { Skor }\end{array}$ & 0 & 0 & 0 & 52 & 85 & 137 & 4,6 \\
\hline \multirow{3}{*}{$\begin{array}{l}\text { Penggunaan } \\
\text { secara turun- } \\
\text { temurun }\end{array}$} & $\begin{array}{l}\text { Jumlah } \\
\text { Orang }\end{array}$ & 0 & 0 & 1 & 21 & 8 & - & - \\
\hline & $\begin{array}{l}\text { Nilai } \\
\text { Skor }\end{array}$ & 0 & 0 & 3 & 84 & 40 & 127 & 4,2 \\
\hline & & & & & & & Total & 13,3 \\
\hline
\end{tabular}

Sumber: Data Primer Diolah, 2020

berbagai ritual upacara adat yang dilaksanakan sesuai dengan kalender suku tengger.

Penilaian masyarakat dalam pemanfaatan tanaman etnobotani pada tabel 3 dan tabel 4 dapat diketahui bahwa persepsi masyarakat dalam pemanfaatan tanaman etnobotani berdasarkan tingkat kebutuhannya pada upacara adat jauh lebih tinggi. Masyarakat Tengger lebih banyak memanfaatkan tanaman etnobotani untuk keperluan upacara adat. Tanaman etnobotani berfungsi sebagai sesajen dalam melaksanakan ritual upacara adat. Berbagai tanaman yang ditetapkan sebagai sesajen sudah menjadi sesuatu yang harus terpenuhi dan dilakukan secara turun-temurun yang merupakan warisan dari para leluhur terdahulu. Berbeda dengan hal tersebut, masyarakat tengger 
yang memanfaatkan tanaman etnobotani sebagai obat herbal justru sangat sedikit. Hal tersebut dapat terjadi karena sudah tidak sesuai dengan kebutuhan masyarakat saat ini. Penggunaan tanaman etnobotani sebagai obat herbal memang merupakan warisan dari generasi tua yang diturunkan secara turun-temurun, namun masyarakat tengger lebih memilih menggunakan obat kimia dibandingkan tanaman obat herbal. Keputusan pemilihan penggunaan obat kimia dilakukan oleh masyarakat tengger karena masyarakat beranggapan bahwa dengan menggunakan obat kimia penyembuhannya bisa lebih cepat jika dibandingkan dengan menggunakan tanaman obat herbal yang penyembuhannya relatif lebih lambat. Masyarakat tengger jika sedang sakit lebih mengutamakan untuk menggunakan alternatif yang lebih cepat walaupun mereka harus mengeluarkan biaya.

\section{Tingkat Penggunaan}

Tingkat penggunaan diartikan seberapa banyaknya tanaman etnobotani yang digunakan oleh masyarakat tengger di Desa Ngadisari baik sebagai obat herbal ataupun sesajen upacara adat. Tingkat penggunaan setiap masyarakat juga berbeda-beda. Besar tingkat penggunaan tanaman etnobotani oleh masyarakat dapat dilihat dari dua kriteria yaitu tingkat frekuensi pemakaian dan tingkat pengguna semua golongan usia. Tingkat frekuensi pemakaian dapat dilihat dari jumlah tanaman etnobotani yang digunakan oleh masyarakat baik untuk obat herbal maupun upacara adat. Tingkat pengguna semua golongan usia dapat dilihat dari seberapa banyak masyarakat dengan usia yang berbeda-beda dalam menggunakan tanaman etnobotani tersebut baik sebagai obat herbal maupun upacara adat. Berikut akan disajikan penilaian masyarakat tengger mengenai tingkat penggunaan terhadap persepsi pemanfaatan tanaman etnobotani sebagai obat herbal.

Berdasarkan tabel 5, dapat diketahui bahwa ada 2 kriteria penilaian yang digunakan antara lain frekuensi pemakaian dan pengguna semua golongan usia. Berdasarkan penilaian tersebut dapat diketahui bahwa penilaian persepsi dalam pemanfaatannya sebagai obat herbal berdasarkan tingkat penggunaannya diperoleh nilai sebesar 3,3. Nilai tersebut berada pada rentang skala $2-3,5$, yang mengartikan bahwa persepsi masyarakat tengger tergolong dalam kategori rendah sekali. Berdasarkan hasil lapang, penggunaan tanaman etnobotani bisa digunakan oleh berbagai golongan usia tetapi harus memperhatikan penyakit dan tanaman yang akan digunakan karena ada beberapa tanaman yang hanya bisa digunakan oleh anak-anak saja, hanya bisa dimanfaatkan oleh orang tua saja bahkan ada juga tanaman yang bisa dimanfaatkan baik oleh anak-anak ataupun orang tua.

Tabel 5

Penilaian Tingkat Penggunaan Terhadap Persepsi Masyarakat dalam Pemanfaatan Tanaman Etnobotani sebagai Obat Herbal

\begin{tabular}{llccccccc}
\hline \multicolumn{1}{c}{ Kriteria } & & $\begin{array}{c}1 \\
\text { Penilaian }\end{array}$ & $\begin{array}{c}2 \\
(\mathrm{RS})\end{array}$ & $\begin{array}{c}3 \\
(\mathrm{R})\end{array}$ & $\begin{array}{c}4 \\
(\mathrm{~T})\end{array}$ & $\begin{array}{c}5 \\
(\mathrm{ST})\end{array}$ & $\begin{array}{c}\text { Total } \\
\text { Skor }\end{array}$ & $\begin{array}{c}\text { Rata-rata } \\
\text { Skor }\end{array}$ \\
\hline $\begin{array}{l}\text { Frekuensi } \\
\text { pemakaian }\end{array}$ & $\begin{array}{l}\text { Jumlah } \\
\text { Orang } \\
\text { Nilai } \\
\text { Skor }\end{array}$ & 22 & 8 & 0 & 0 & 0 & - & - \\
& 22 & 16 & 0 & 0 & 0 & 38 & 1,3 \\
$\begin{array}{l}\text { Pengguna } \\
\text { semua } \\
\text { golongan usia }\end{array}$ & $\begin{array}{l}\text { Jumlah } \\
\text { Orang }\end{array}$ & 12 & 7 & 11 & 0 & 0 & - & - \\
$\begin{array}{l}\text { Nilai } \\
\text { Skor }\end{array}$ & 12 & 14 & 33 & 0 & 0 & 59 & 2,0 \\
\hline
\end{tabular}

Sumber: Data Primer Diolah, 2020 
Tanaman etnobotani memang lebih aman untuk dikonsumsi jika dibandingkan dengan obat kimia, akan tetapi saat ini frekuensi pemakaian tanaman etnobotani sebagai obat herbal sangat kecil. Masyarakat tengger yang berada di Desa Ngadisari saat ini banyak yang memilih untuk menggunakan obat kimia karena proses penyembuhannya lebih cepat walaupun mereka harus mengeluarkan biaya untuk membeli obat tersebut. Menurut Sari dkk. (2015), salah satu faktor yang mempengaruhi penggunaan dan pemanfaatan tanaman obat yaitu faktor sosial budaya. Faktor tersebut terlihat jelas dimana masyarakat tua saja yang masih menggunakan tanaman obat dan mempertahankan tradisi tersebut. Kaum muda sepertinya sudah tidak begitu peduli dengan penggunaan tanaman obat sehingga saat ini tanaman obat semakin sulit ditemukan karena kurangnya minat masyarakat dalam membudidayakan tanaman obat tersebut.

Persepsi masyarakat Tengger di Desa Ngadisari Kecamatan Sukapura Kabupaten Probolinggo berdasarkan tingkat penggunaan dalam upacara adat didasarkan atas 2 kriteria penilaian. Adapun kriteria penilaian yang digunakan yaitu frekuensi pemakaian dan pengguna semua golongan usia. Berikut akan disajikan tabel mengenai penilaian masyarakat Tengger berdasarkan tingkat penggunaannya dalam pemanfaatan tanaman etnobotani dalam upacara adat.

Berdasarkan tabel 6, dapat diketahui penilaian masyarakat tengger dalam pemanfaatan tanaman etnobotani dalam upacara adat berdasarkan indikator tingkat penggunaan. Terdapat 2 kriteria penilaian yang digunakan pada tingkat penggunaan antara lain frekuensi pemakaian dan pengguna semua golongan usia. Berdasarkan tingkat penggunaan dalam upacara adat diperoleh nilai sebesar 7,5. Perolehan nilai tersebut berada pada rentang skala 6,8 - 8,3, dimana dapat disimpulkan bahwa persepsi masyarakat Tengger yang berada di Desa Ngadisari Kecamatan Sukapura Kabupaten Probolinggo dalam pemanfaatan tanaman etnobotani untuk keperluan upacara adat tergolong dalam kategoritinggi. Masyarakat Tengger di Desa Ngadisari hingga saat ini selalu menggunakan tanaman etnobotani sebagai sesajen, dimana tanaman tersebut sudah ditetapkan jenis-jenis tanaman yang digunakan untuk ritual upacara adat oleh leluhur-leluhur sebelumnya. Hingga saat ini ketentuan dalam penggunaan tanaman sebagai sesajen dalam mengikuti ritual upacara adat masih digunakan oleh masyarakat tengger karena hal itu menjadi suatu warisan dari leluhur terdahulu dan tidak bisa diganti sebab setiap tanaman memiliki makna yang berbeda-beda.

Tabel 6

Penilaian Tingkat Penggunaan Terhadap Persepsi Masyarakat dalam Pemanfaatan Tanaman Etnobotani dalam Upacara Adat

\begin{tabular}{llccccccc}
\hline Kriteria Penilaian & $\begin{array}{c}1 \\
(\mathrm{RS})\end{array}$ & $\begin{array}{c}2 \\
(\mathrm{R})\end{array}$ & $\begin{array}{c}3 \\
(\mathrm{CT})\end{array}$ & $\begin{array}{c}4 \\
(\mathrm{~T})\end{array}$ & $\begin{array}{c}5 \\
(\mathrm{ST})\end{array}$ & $\begin{array}{c}\text { Total } \\
\text { Skor }\end{array}$ & $\begin{array}{c}\text { Rata-rata } \\
\text { Skor }\end{array}$ \\
\hline $\begin{array}{l}\text { Frekuensi } \\
\text { pemakaian }\end{array}$ & $\begin{array}{l}\text { Jumlah } \\
\text { Orang } \\
\text { Nilai }\end{array}$ & 0 & 0 & 0 & 15 & 15 & - & - \\
& 0 & 0 & 0 & 60 & 75 & 135 & 4,5 \\
$\begin{array}{l}\text { Skor } \\
\text { Pengguna }\end{array}$ & $\begin{array}{l}\text { Jumlah } \\
\text { semua golongan } \\
\text { usia }\end{array}$ & 0 & 2 & 25 & 3 & 0 & - & - \\
$\begin{array}{l}\text { Orang } \\
\text { Nilai } \\
\text { Skor }\end{array}$ & 0 & 4 & 75 & 12 & 0 & 91 & 3,0 \\
& & & & & & & Total & 7,5 \\
\hline
\end{tabular}

Sumber: Data Primer Diolah, 2020 
Hasil penilaian persepsi pada tingkat penggunaan baik sebagai obat herbal maupun upacara adat tentu berbeda. Berdasarkan tabel 5 dan 6, dapat diketahui bahwa penilaian tingkat penggunaan terhadap persepsi masyarakat tengger dalam pemanfaatan tanaman etnobotani sebagai upacara adat lebih tinggi jika dibandingkan dengan pemanfaatan pada obat herbal. Semua masyarakat Tengger yang berada di Desa Ngadisari Kecamatan Sukapura Kabupaten Probolinggo baik yang muda ataupun yang tua menggunakan tanaman etnobotani untuk sesajen dalam mengikuti ritual upacara adat, dimana pelaksanaan upacara adat Tengger sudah ditetapkan di kalender suku Tengger dan dilaksanakan sesuai kalender tengger tersebut.

Seperti halnya yang dilakukan oleh masyarakat Aceh, mereka memiliki kaitan yang erat dengan berbagai upacara adat dimana tidak pernah lepas dari bahanbahan yang diambil dari alam. Upacara adat masyarakat Aceh sangat banyak menggunakan aneka ragam tanaman sebagai perlengkapan ritual upacara adat. Pengetahuan mengenai penggunaan tanaman tersebut merupakan warisan dari leluhurnya. Pemahaman masyarakat Aceh dalam penggunaannya pada upacara adat sangat baik sehingga tidak ada kesalahan dalam penggunaannya dimana setiap tanaman tersebut memiliki nilai filosofi/ makna masing-masing (Rahimah dkk., 2019).

Berbeda dengan hal tersebut, pemanfaatan tanaman etnobotani sebagai obat herbal oleh masyarakat Tengger yang berada di Desa Ngadisari sangat sedikit. Frekuensi pemakaian tanaman etnobotani sebagai obat herbal saat ini mulai berkurang sehingga menyebabkan ketersediaan tanaman tersebut menjadi menurun. Penyebabnya yaitu rendahnya minat masyarakat tengger dalam melakukan budidaya tanaman obat herbal dimana mereka merasa sudah tidak membutuhkannya lagi. Bahkan ada beberapa masyarakat tengger yang memangkas tanaman obat herbal karena dianggap kotor. Padahal tanaman obat herbal lebih aman untuk dikonsumsi oleh berbagai golongan usia, dimana penggunaannya juga menyesuaikan dengan penyakit yang dialami.

\section{Tingkat Keberhasilan}

Tingkat keberhasilan diartikan seberapa banyak masyarakat tengger yang memanfaatkan tanaman etnobotani, dimana hal tersebut menjadi tolak ukur untuk mengetahui keberhasilan dari pemanfaatan tanaman etnobotani. Besar tingkat keberhasilan pemanfaatan tanaman etnobotani dapat dilihat dari 2 kriteria yaitu tingkat penggunaan tanaman etnobotani dan konsistensi penggunaan.

Tabel 7

Penilaian Tingkat Keberhasilan Terhadap Persepsi Masyarakat dalam PemanfaatanTanaman Etnobotani sebagai Obat Herbal

\begin{tabular}{clccccccc}
\hline Kriteria Penilaian & & $\begin{array}{c}1 \\
(\mathrm{RS})\end{array}$ & $\begin{array}{c}2 \\
(\mathrm{R})\end{array}$ & $\begin{array}{c}3 \\
(\mathrm{CT})\end{array}$ & $\begin{array}{c}4 \\
(\mathrm{~T})\end{array}$ & $\begin{array}{c}5 \\
(\mathrm{ST})\end{array}$ & $\begin{array}{c}\text { Total } \\
\text { Skor }\end{array}$ & $\begin{array}{c}\text { Rata-rata } \\
\text { Skor }\end{array}$ \\
\hline $\begin{array}{l}\text { Penggunaan tanaman } \\
\text { obat oleh masyarakat }\end{array}$ & $\begin{array}{l}\text { Jumlah } \\
\text { Orang }\end{array}$ & 14 & 16 & 0 & 0 & 0 & - & - \\
& $\begin{array}{l}\text { Nilai } \\
\text { Skor }\end{array}$ & 14 & 32 & 0 & 0 & 0 & 46 & 1,5 \\
& $\begin{array}{l}\text { Jumlah } \\
\text { Orang } \\
\text { Nilai } \\
\text { Skor }\end{array}$ & 22 & 8 & 0 & 0 & 0 & - & - \\
& 16 & 0 & 0 & 0 & 38 & 1,3 \\
\hline
\end{tabular}

Sumber: Data Primer Diolah, 2020 
Tingkat penggunaan tanaman etnobotani baik sebagai obat herbal maupun upacara adat dilihat dari seberapa banyak masyarakat tengger yang masih bertahan dalam memanfaatkan tanaman etnobotani hingga saat ini. Tingkat konsistensi penggunaan dilihat dari seberapa banyak masyarakat tengger yang saat ini tetap konsisten dalam memanfaatkan tanaman tersebut untuk obat herbal maupun upacara adat. Berikut akan disajikan penilaian masyarakat Tengger yang berada di Desa Ngadisari Kecamatan Sukapura Kabupaten Probolinggo berdasarkan tingkat keberhasilan terhadap persepsi pemanfaatan tanaman obat herbal.

Berdasarkan tabel 7, dapat diketahui penilaian masyarakat dalam pemanfaatan tanaman etnobotani sebagai obat herbal pada indikator tingkat keberhasilan. Terdapat 2 kriteria penilaian yang digunakan antara lain penggunaan tanaman obat oleh masyarakat dan konsistensi penggunaan. Berdasarkan tingkat keberhasilannya dapat diketahui bahwa hasil dari penilaian persepsi dengan menggunakan 2 kriteria penilaian dihasilkan nilai sebesar 2,8. Nilai tersebut berada dalam rentang skala antara 2-3,5, dimana nilai 2,8 mengartikan bahwa persepsi masyarakat dalam pemanfaatan tanaman etnobotani sebagai obat herbal jika dilihat berdasarkan tingkat keberhasilannya masih tergolong dalam kategori rendah sekali. Berdasarkan hasil lapang, masyarakat Tengger saat ini lebih memilih untuk menggunakan obat kimia karena penggunaannya lebih praktis dan penyembuhannya juga lebih cepat jika dibandingkan dengan menggunakan tanaman obat herbal yang dinilai lebih rumit karena harus melakukan suatu perlakuan baik itu dihaluskan, direbus, ditumbuk dan lain sebagainya. Selain itu, perkembangan zaman yang semakin maju banyak tersedia obat-obatan kimia untuk berbagai jenis penyakit. Walaupun ada beberapa obat yang harganya mahal, tetapi mereka lebih memilih untuk menggunakan obat kimia meskipun harus mengeluarkan biaya. Mereka lebih mengutamakan proses penyembuhan yang cepat, sehingga saat ini mereka banyak yang beralih menggunakan obat kimia.

Penilaian persepsi masyarakat Tengger di Desa Ngadisari Kecamatan Sukapura Kabupaten Probolinggo berdasarkan tingkat keberhasilannya dalam pemanfaatannya pada upacara adat menggunakan 2 kriteria penilaian. Adapun kriteria penilaian yang digunakan antara lain penggunaan tanaman keperluan upacara adat oleh masyarakat dan konsistensi penggunaan (Tabel 8).

Berdasarkan tabel 8, dapat diketahui penilaian masyarakat tengger dalam pemanfaatan tanaman etnobotani untuk upacara adat pada indikator tingkat keberhasilan. Terdapat 2 kriteria penilaian

Tabel 8

\section{Penilaian Tingkat Keberhasilan Terhadap Persepsi Masyarakat dalam} Pemanfaatan Tanaman Etnobotani dalam Upacara Adat

\begin{tabular}{|c|c|c|c|c|c|c|c|c|}
\hline Kriteria Penilaian & & $\begin{array}{c}1 \\
\text { (RS) }\end{array}$ & $\begin{array}{c}2 \\
(\mathrm{R})\end{array}$ & $\begin{array}{c}3 \\
(\mathrm{CT}) \\
\end{array}$ & $\begin{array}{c}4 \\
(T)\end{array}$ & $\begin{array}{c}5 \\
(\mathrm{ST}) \\
\end{array}$ & $\begin{array}{l}\text { Total } \\
\text { Skor }\end{array}$ & $\begin{array}{c}\text { Rata-rata } \\
\text { Skor }\end{array}$ \\
\hline \multirow{2}{*}{$\begin{array}{l}\text { Penggunaan } \\
\text { tanaman } \\
\text { keperluan } \\
\text { upacara adat oleh } \\
\text { masyarakat }\end{array}$} & $\begin{array}{l}\text { Jumlah } \\
\text { Orang }\end{array}$ & 0 & 0 & 0 & 14 & 16 & - & - \\
\hline & $\begin{array}{l}\text { Nilai } \\
\text { Skor }\end{array}$ & 0 & 0 & 0 & 56 & 80 & 136 & 4,5 \\
\hline \multirow[t]{3}{*}{$\begin{array}{l}\text { Konsistensi } \\
\text { penggunaan }\end{array}$} & $\begin{array}{l}\text { Jumlah } \\
\text { Orang }\end{array}$ & 0 & 0 & 0 & 15 & 15 & - & - \\
\hline & $\begin{array}{l}\text { Nilai } \\
\text { Skor }\end{array}$ & 0 & 0 & 0 & 60 & 75 & 135 & 4,5 \\
\hline & & & & & & & Total & 9,0 \\
\hline
\end{tabular}

Sumber: Data Primer Diolah, 2020 
yang digunakan antara lain penggunaan tanaman keperluan upacara adat oleh masyarakat dan konsistensi penggunaan. Penilaian persepsi masyarakat tengger dalam pemanfaatan tanaman etnobotani sebagai upacara adat berdasarkan tingkat keberhasilannya menghasilkan nilai sebesar 9,0. Nilai 9,0 tersebut berada pada rentang skala 8,4-10 yang mengartikan bahwa persepsi masyarakat tengger di Desa Ngadisari Kecamatan Sukapura Kabupaten Probolinggo dalam pemanfaatan tanaman etnobotani sebagai upacara adat tergolong dalam kategori sangat tinggi. Hal tersebut mengartikan bahwa saat ini masyarakat tengger di Desa Ngadisari masih banyak yang menggunakan tanaman etnobotani sebagai sesajen dalam mengikuti berbagai ritual upacara adat.

Penilaian masyarakat tengger di Desa Ngadisari Kecamatan Sukapura Kabupaten Probolinggo dalam pemanfaatan tanaman etnobotani yang disajikan pada tabel 7 dan tabel 8 tentu menghasilkan nilai yang berbeda. Nilai persepsi masyarakat tengger dalam pemanfaatan tanaman etnobotani sebagai sesajen pada upacara adat lebih tinggi jika dibandingkan dengan pemanfaatan tanaman etnobotani sebagai obat herbal. Keberhasilan penggunaan tanaman etnobotani dalam upacara adat dapat dilihat dari banyaknya masyarakat tengger yang masih menggunakan tanaman etnobotani sebagai sesajen pada upacara adat. Masyarakat tengger dari dulu hingga saat ini masih tetap konsisten dalam menggunakan tanaman etnobotani sebagai sesajen upacara adat sesuai dengan ketentuan yang telah ditetapkan leluhur-leluhurnya. Berbeda dengan hal tersebut, masyarakat tengger di Desa Ngadisari Kecamatan Sukapura Kabupaten Probolinggo yang memanfaatkan tanaman etnobotani sebagai obat herbal saat ini justru mulai berkurang. Masyarakat tengger sudah banyak yang beralih menggunakan obat kimia. Masyarakat tengger beranggapan bahwa tanaman etnobotani yang digunakan sebagai obat herbal hanya sekedar dibutuhkan untuk menjaga kesehatan serta untuk menyembuhkan penyakit yang dianggap ringan saja.

\section{Tingkat Kemudahan Bahan Didapat}

Tingkat kemudahan bahan didapat diartikan seberapa banyak ketersediaan tanaman etnobotani di lingkungan sekitar. Besar tingkat kemudahan bahan didapat bisa dilihat dari dua kriteria yaitu tingkat kemudahan tanaman etnobotani didapatkan dan tingkat ketersediaan tanaman di hutan atau tegal. Tingkat kemudahan tanaman etnobotani untuk didapatkan dapat dilihat dari seberapa mudahnya masyarakat mendapatkan tanaman etnobotani di sekitar lingkungan.

Tabel 9

Penilaian Tingkat Kemudahan Bahan Didapat Terhadap Persepsi Masyarakat dalam Pemanfaatan Tanaman Etnobotani sebagai Obat Herbal

\begin{tabular}{llccccccc}
\hline Kriteria Penilaian & & $\begin{array}{c}1 \\
(\mathrm{RS})\end{array}$ & $\begin{array}{c}2 \\
(\mathrm{R})\end{array}$ & $\begin{array}{c}3 \\
(\mathrm{CT})\end{array}$ & $\begin{array}{c}4 \\
(\mathrm{~T})\end{array}$ & $\begin{array}{c}5 \\
(\mathrm{ST})\end{array}$ & $\begin{array}{c}\text { Total } \\
\text { Skor }\end{array}$ & $\begin{array}{c}\text { Rata-rata } \\
\text { Skor }\end{array}$ \\
\hline $\begin{array}{l}\text { Kemudahan } \\
\text { tanaman obat }\end{array}$ & $\begin{array}{l}\text { Jumlah } \\
\text { Orang }\end{array}$ & 10 & 20 & 0 & 0 & 0 & - & - \\
$\begin{array}{l}\text { Nilai } \\
\text { untuk didapatkan }\end{array}$ & 10 & 40 & 0 & 0 & 0 & 50 & 1,7 \\
$\begin{array}{l}\text { Ketersediaan } \\
\text { Jumlah } \\
\text { tanaman obat di } \\
\text { tegal/ hutan }\end{array}$ & $\begin{array}{l}\text { Orang } \\
\text { Nilai } \\
\text { Skor }\end{array}$ & 9 & 21 & 0 & 0 & 0 & - & - \\
& 42 & 0 & 0 & 0 & 51 & 1,7 \\
\hline
\end{tabular}

Sumber: Data Primer Diolah, 2020 
Tingkat ketersediaan tanaman di hutan/ tegal dapat dilihat dari seberapa banyaknya tanaman etnobotani yang saat ini masih tersedia di hutan/tegal. Berikut akan disajikan penilaian masyarakat tengger berdasarkan tingkat kemudahan bahan didapat terhadap persepsi pemanfaatan tanaman etnobotani sebagai obat herbal.

Berdasarkan tabel 9, dapat diketahui penilaian masyarakat tengger dalam pemanfaatan tanaman etnobotani sebagai obat herbal pada indikator tingkat kemudahan bahan didapat. Terdapat 2 kriteria penilaian yang digunakan antara lain kemudahan tanaman obat untuk didapatkan dan ketersediaan tanaman obat di hutan/tegal. Berdasarkan tingkat kemudahan bahan didapat dapat diketahui bahwa hasil dari penilaian persepsi dengan menggunakan 2 kriteria penilaian dihasilkan nilai sebesar 3,4 , dimana nilai tersebut berada pada rentang skala $2-3,5$. Nilai 3,4 tersebut mengartikan bahwa persepsi masyarakat Tengger yang berada di Desa Ngadisari Kecamatan Sukapura Kabupaten Probolinggo dalam pemanfaatan tanaman etnobotani sebagai obat herbal tergolong rendah sekali. Berdasarkan hasil lapang, dapat diketahui bahwa ketersediaan dari tanaman etnobotani yang digunakan oleh masyarakat Tengger yang berada di Desa Ngadisari Kecamatan Sukapura Kabupaten Probolinggo sebagai obat herbal sudah mulai berkurang, sehingga keberadaan tanaman obat herbal saat ini mulai susah ditemukan oleh masyarakat di Desa Ngadisari. Hal tersebut dapat terjadi akibat rendahnya minat masyarakat untuk melakukan budidaya tanaman etnobotani dan masyarakat merasa sudah tidak membutuhkan tanaman obat herbal khususnya dalam menyembuhkan penyakit.

Penilaian persepsi masyarakat Tengger di Desa Ngadisari Kecamatan Sukapura Kabupaten Probolinggo berdasarkan tingkat kemudahan bahan didapat dalam pemanfaatannya pada upacara adat juga menggunakan 2 kriteria penilaian. Adapun kriteria penilaian yang digunakan antara lain kemudahan tanaman upacara adat untuk didapatkan dan ketersediaan tanaman etnobotani untuk upacara adat di hutan/tegal. Berikut akan disajikan tabel mengenai penilaian masyarakat tengger dalam pemanfaatan tanaman etnobotani untuk keperluan upacara adat.

Berdasarkan tabel 10, dapat diketahui bahwa besar nilai persepsi masyarakat dalam pemanfaatan tanaman etnobotani untuk keperluan upacara adat menghasilkan total nilai sebesar 8,9. Nilai 8,9 berada pada rentang skala antara 8,4-10 yang mengartikan bahwa persepsi masyarakat dalam pemanfaatan tanaman etnobotani pada upacara adat tergolong sangat tinggi. Ketersediaan tanaman dalam upacara adat sangat banyak, sehingga mudah ditemukan. Seperti halnya penelitian yang dilakukan oleh

Tabel 10

Penilaian Tingkat Kemudahan Bahan Didapat Terhadap Persepsi Masyarakat dalam Pemanfaatan Tanaman Etnobotani dalam Upacara Adat

\begin{tabular}{|c|c|c|c|c|c|c|c|c|}
\hline Kriteria Penilaian & & $\begin{array}{c}1 \\
(\mathrm{RS})\end{array}$ & $\begin{array}{c}2 \\
(\mathrm{R})\end{array}$ & $\begin{array}{c}3 \\
\text { (CT) }\end{array}$ & $\begin{array}{c}4 \\
(\mathrm{~T})\end{array}$ & $\begin{array}{c}5 \\
\text { (ST) }\end{array}$ & $\begin{array}{l}\text { Total } \\
\text { Skor }\end{array}$ & $\begin{array}{c}\text { Rata-rata } \\
\text { Skor }\end{array}$ \\
\hline \multirow{2}{*}{$\begin{array}{l}\text { Kemudahan tanaman } \\
\text { upacara adat untuk } \\
\text { didapatkan }\end{array}$} & $\begin{array}{l}\text { Jumlah } \\
\text { Orang }\end{array}$ & 0 & 0 & 0 & 17 & 13 & - & - \\
\hline & $\begin{array}{l}\text { Nilai } \\
\text { Skor }\end{array}$ & 0 & 0 & 0 & 68 & 65 & 133 & 4,4 \\
\hline \multirow[t]{3}{*}{$\begin{array}{l}\text { Ketersediaan tanaman } \\
\text { obat di tegal/ hutan }\end{array}$} & $\begin{array}{l}\text { Jumlah } \\
\text { Orang }\end{array}$ & 0 & 0 & 0 & 15 & 15 & - & - \\
\hline & $\begin{array}{l}\text { Nilai } \\
\text { Skor }\end{array}$ & 0 & 0 & 0 & 60 & 75 & 135 & 4,5 \\
\hline & & & & & & & Total & 8,9 \\
\hline
\end{tabular}

Sumber: Data Primer Diolah, 2020 
Illiyyin dkk. (2019), bahwa tumbuhan yang digunakan dalam upacara adat semuanya sudah tersedia di alam sehingga masyarakat tinggal mengambilnya dari sawah, pekarangan rumah dan di sekitar jalan desa. Ketersediaan tanaman untuk ritual upacara adat sangat banyak, namun tanaman yang diambil jumlahnya tidak banyak sehingga nisa digunakan untuk pelaksanaan ritual upacara adat selanjutnya.

Penilaian masyarakat tengger dalam pemanfaatan tanaman etnobotani pada tabel 9 dan 10 menunjukkan bahwa nilai persepsi pemanfaatan tanaman etnobotani dalam upacara adat lebih tinggi. Ketersediaan tanaman yang dibutuhkan dalam upacara adat nyatanya lebih banyak, sehingga masyarakat mudah mendapatkannya. Tanaman etnobotani yang selalu digunakan dalam upacara adat yaitu edelweis, kenikir dan putihan. Tanaman edelweis menjadi tanaman khas Tengger, dimana saat ini sudah dibudidayakan di Taman Nasional Bromo Tengger Semeru, sedangkan tanaman putihan dan kenikir banyak ditemukan di tegal/ hutan namun ada juga masyarakat yang menanamnya sendiri. Berbeda halnya dengan tanaman etnobotani yang digunakan sebagai obat herbal, ketersediaannya mengalami penurunan karena rendahnya minat masyarakat untuk melakukan budidaya.

Keseluruhan penilaian persepsi masyarakat Tengger dalam pemanfaatan tanaman etnobotani memiliki hasil yang berbeda-beda. Berikut akan disajikan penilaian keseluruhan kriteria dalam pemanfaatan tanaman etnobotani.

Berdasarkan tabel 11, dapat diketahui bahwa penilaian persepsi masyarakat tengger dalam pemanfaatan tanaman etnobotani sebagai obatherbal lebih rendah jika dibandingkan dengan pemanfaatan sebagai upacara adat. Nilai yang diperoleh dalam pemanfaatan sebagai obat herbal yaitu sebesar 13,9, dimana nilai tersebut termasuk dalam kategori rendah sekali karena berada pada rentang skor $9-16,1$. Berdasarkan hasil lapang menjelaskan bahwa saat ini masyarakat Tengger banyak yang beralih menggunakan obat kimia. Hal tersebut nyatanya juga terjadi pada masyarakat Tengger yang berada di Kabupaten Lumajang dan Kabupaten Malang. Berdasarkan penelitian Ningsih (2016), pengetahuan Masyarakat Suku Tengger yang mendiami wilayah Kabupaten Lumajang dan Kabupaten Malang saat ini juga mulai terancam punah akibat adanya perubahan sosio-budaya, dimana pengetahuan masyarakat mengenai obat herbal hanya sebatas pada generasi tua saja. Generasi muda saat ini lebih memilih untuk menggunakan alternatif pengobatan yang lebih praktis dan lebih cepat proses penyembuhannya misalnya dengan cara berobat ke mantri, puskesmas, polindes ataupun yang lainnya.

Nilai persepsi yang diperoleh dalam pemanfaatan tanaman etnobotani sebagai upacara adat yaitu sebesar 38,7, dimana nilai tersebut termasuk dalam kategori sangat tinggi karena berada pada rentang skor 37,8 - 45. Hasil lapang menunjukkan

Tabel 11

Penilaian Persepsi Masyarakat Terhadap Kriteria Pemanfaatan Tanaman Etnobotani

\begin{tabular}{clcc}
\hline No & \multicolumn{1}{c}{ Kriteria } & \multicolumn{2}{c}{ Rata-Rata Skor } \\
\cline { 3 - 4 } & & Obat Herbal & Upacara Adat \\
\hline 1 & Tingkat Kebutuhan & $4,4(\mathrm{RS})$ & $13,3(\mathrm{ST})$ \\
2 & Tingkat Penggunaan & $3,3(\mathrm{RS})$ & $7,5(\mathrm{~T})$ \\
3 & Tingkat Keberhasilan & $2,8(\mathrm{RS})$ & $9,0(\mathrm{ST})$ \\
4 & Tingkat Kemudahan Bahan Didapat & $3,4(\mathrm{RS})$ & $8,9(\mathrm{ST})$ \\
& $\quad$ Jumlah & $13,9(\mathrm{RS})$ & $38,7(\mathrm{ST})$ \\
\hline
\end{tabular}

Sumber: Data Primer Diolah, 2020 
bahwa masyarakat Tengger di Desa Ngadisari Kecamatan Sukapura Kabupaten Probolinggo lebih banyak memanfaatkan tanaman etnobotani untuk keperluan upacara adat sehingga sebagian besar masyarakat membudidayakannya karena mereka sangat membutuhkan tanaman tersebut untuk digunakan sebagai sesajen ritual upacara adat. Hal tersebut juga terjadi pada Masyarakat Moronene yang berada di Sulawesi Tenggara, dimana mereka juga memanfaatkan tanaman sebagai keperluan upacara adat. Menurut Setiawan \& Qiptiyah (2014), Suku Moronene memiliki interaksi yang sangat kuat dengan alam dan lingkungan yang ada di sekitarnya.

\section{SIMPULAN}

Persepsi masyarakat Tengger di Desa Ngadisari Kecamatan Sukapura Kabupaten Probolinggo dalam pemanfaatan tanaman etnobotani untuk obat herbal tergolong rendah sekali dengan nilai sebesar 13,9. Hal tersebut dapat terjadi karena rendahnya minat masyarakat untuk melakukan budidaya sehingga banyak yang beralih ke obat kimia. Persepsi masyarakat dalam pemanfaatan tanaman etnobotani untuk keperluan upacara adat tergolong sangat tinggi dengan nilai sebesar 38,7 . Nilai tersebut menunjukkan bahwa masyarakat tengger membutuhkan tanaman etnobotani sebagai sesajen ritual upacara adat.

\section{DAFTAR PUSTAKA}

Astriyantika, M., Arief, H., \& Sunarminto, T. (2014). Studi Konservasi Sumberdaya Alam Hayati Pada Masyarakat Tengger Di Resort Ranu Pani, Taman Nasional Bromo Tengger Semeru. Media Konservasi, 19(1), 1-11. https://Doi. Org/10.29244/Medkon.19.1.
Badan Pusat Statistik. (2019). Kecamatan Sukapura Dalam Angka 2019. Probolinggo: Badan Pusat Statistik Kabupaten Probolinggo. https:// probolinggokab.bps.go.id/publicatio n/2019/09/26/244a66aa3d1246d78d ad1fb8/kecamatan-sukapura-dalamangka-2019.html.

Batoro, J. (2015). Pengelolaan Lingkungan Dengan Pendekatan EtnobiologiEtnobotani. Malang: UB Press. https://books.google.co.id/books?id $=$ WvIRDwAAQBAJ\&pg=PA98\&dq=B atoro,+J.+(2015).+Pengelolaan+Lin gkungan+Dengan+Pendekatan+Etn obiologi-Etnobotani.

Batoro, J. (2017). Kejaiban Bromo Tengger Semeru Analisis Kehidupan Suku Tengger-Antropologi-Biologi Di Lingkungan Bromo Tengger Semeru Jawa Timur. Malang: Universitas Brawijaya Press. https://books. google.co.id/books?id=82JVDwAA QBAJ\&pg=PA139\&dq=Batoro,+J.+ (2015).+Pengelolaan+Lingkungan+ Dengan+Pendekatan+EtnobiologiEtnobotani.

Batoro, J., Setiadi, D., Chikmawati, T., \& Purwanto, Y. (2011). Pengetahuan Tentang Tumbuhan Masyarakat Tengger Di Bromo Tengger Semeru Jawa Timur. Journal Of Biota, 14(1), 1-10. https://Doi.Org/10.24002/ Biota.V17i1.128.

Diana Sari, I., Yuniar, Y., Siahaan, S., \& Al, E. (2015). Community Tradition In Planting And Using Medicinal Plant In Surround Home Yard. Indonesian Pharmaceutical Journal, 
Eko Atmojo, S. (2015). Pengenalan Etnobotani Pemanfaatan Tanaman Sebagai Obat Kepada Masyarakat Desa Cabak Jiken Kabupaten Blora. Jurnal IImiah Wuny, 15(1). Https://Doi.Org/10.21831/Jwuny. V15i1.3529

Hasanah, U., Linda, R., \& Lovadi, I. (2014). Pemanfaatan Tumbuhan Pada Upacara Adat Tumpang Negeri Suku Melayu Di Keraton Ismahayana Landak. Protobiont, 3(3), 17-24. https://jurnal.untan.ac.id/index.php/ jprb/article/view/7355

Illiyyin, R., Hayati, A., \& Zayadi, H. (2019). Studi Etnobotani Pada Upacara Adat "Pujan Kasanga" Di Desa Tosari Pasuruan. Biosainstropis, 4, 1-7. http://biosaintropis.unisma. ac.id/index.php/biosaintropis/article/ view/157

Indarwati, V., Soetriono, \& Sudarko. (2015). Analisis Kelayakan Finansial, Nilai Tambah Dan Strategi Pengembangan Komoditas Salak Di Kabupaten Jember. JSEP, 8(3), 2537. http://jurnal.unej.ac.id/index.php/ JSEP/article/view/3757.

Juwita, T., Prasmatiwi, F. E., \& Santoso, H. (2014). ManfaatFinansial Pembinaan Dan Verifikasi kopi dalam upaya peningkatan mutu kopi: studi kasus program verifikasi binaan pt nastle indonesia di kabupaten tanggamus. Jurnal IImu-IImu Agribisnis, 2(3), 276-284. http://jurnal.fp.unila.ac.id/ index.php/JIA/article/view/811/741.

Kurniawan, E., \& Jadid, N. (2015). Nilai Guna Spesies Tanaman Sebagai Obat Tradisional Oleh Masyarakat Tengger Di Desa Ngadisari Kecamatan Sukapura, Kabupaten Probolinggo - Jawa Timur. Jurnal Sains Dan Seni Its, 4(1), 1-4. http:// ejurnal.its.ac.id/index.php/sains seni/article/view/8582.
Ningsih, I. Y. (2016). Studi Etnofarmasi Penggunaan Tumbuhan Obat Oleh Suku Tengger Di Kabupaten Lumajang Dan Malang, Jawa Timur. Pharmachy, 13(01), 10-20. http:// jurnalnasional.ump.ac.id/index.php/ PHARMACY/article/view/885.

Panuju, R. (2018). Pengantar Studi (IImu) Komunikasi. Kencana. https://books. google.co.id/books?id=fDa2DwAAQ BAJ\&printsec $=$ frontcover\&dq=ilmu+ komunikasi+suatu+pengantar.

Pramita, N. H., Indriyani, S., \& Hakim, L. (2013). Etnobotani Upacara Kasada Masyarakat Tengger, Di Desa Ngadas, Kecamatan Poncokusumo, Kabupaten Malang. Journal Of Indonesian Tourism And Development Studies, 1(2), 52-61. https://www.neliti.com/ publications/29327/etnobotaniupacara-kasada-masyarakattengger-di-desa-ngadas-kecamatanmalang-pon

Rahimah, R., Hasanuddin, H., \& Djufri, D. (2019). Kajian Etnobotani (Upacara Adat Suku Aceh Di Provinsi Aceh). Biotik: Jurnal Ilmiah Biologi Teknologi Dan Kependidikan, 6(1), 53. Https:// Doi.Org/10.22373/Biotik.V6i1.4045

Riduwan. (2018). Dasar-Dasar Statistika. Bandung: Alfabeta.

Savitri, A. (2016). Tanaman Ajaib! Basi Penyakit Dengan Toga (Tanaman Obat Keluarga). Depok: Bibit Publisher. Https://Books.Google. Co.ld/Books?HI=Id\&Lr=\&Id=Mnom dgaaqbaj\&Oi=Fnd\&Pg $=\mathrm{Pa} 1 \& \mathrm{Dq}=$ Jumlah+Tanaman+Obat+Di+Indo nesia\&Ots $=J j e g v e u l b p \& S i g=B v e v$ cyzttmo7mltb-1dpxxfwcry\&Redir Esc $=Y \# V=$ Onepage \&Q $=\mathrm{Jumla} \bar{h}$ Tanaman Obat Di Indonesia\&F=False 
Setiawan, H., \& Qiptiyah, M. (2014). Kajian Etnobotani Masyarakat Adat Suku Moronene Di Taman Nasional Rawa Aopawatumohai. Penelitian Kehutanan Wallacea, 3(2), 107-117.

Sidik, V. D. P. N., \& Fatmawati, I. (2019). Persepsi Masyarakat Terhadap Peran Etnofarmaka Temu Ireng Di Kecamatan Rubaru Kabupaten Sumenep. Prosiding Seminar Nasional Ekonomi Dan Teknologi, 248-259. https://ejournalwiraraja. com/index.php/PROSD/article/ view/837. https://www.jurnal. balithutmakassar.org/index.php/ wallacea/article/view/38
Ukkas, M. I. (2017). Implementasi Skala Likert Pada Metode Perbandingan Eksponensial Untuk Menentukan Pilihan Asuransi. Seminar Nasional Sistem Informasi Indonesia, 9, 99104. https://scholar.google.com/ scholar?hl=id\&as_sdt=0\%2C5\&q=I mplementasi+Skala+Likert+Pada+M etode+Perbandingan+Eksponensial + Untuk+Menentukan+Pilihan+Asura nsi\&btnG $=$.

Walujo, E. B. (2011). Sumbangan IImu Etnobotani dalam Memfasilitasi Hubungan Manusia dengan Tumbuhan dan Lingkungannya. Jurnal Biologi Indonesia, 7(2), 375-391. https://e-journal.biologi. lipi.go.id/index.php/jurnal_biologi_ indonesia/article/viewFile/3122/270 